\title{
An Investigation of Textile Wastewater Treatment using Chlorella vulgaris
}

\author{
P. S. SUBASHINI and P. RAJIV* \\ Department of Biotechnology, Karpagam Academy of Higher Education, Coimbatore, India. \\ ${ }^{*}$ Corresponding author E-mail: rajivsmart15@gmail.com \\ http://dx.doi.org/10.13005/ojc/340538
}

(Received: March 23, 2018; Accepted: August 03, 2018)

\begin{abstract}
An uptake system for the bio-remediation of textile wastewater using Chlorella vulgaris DPSF01. Chlorella vulgaris is mass cultured in raw textile wastewater diluted with normal tap water and the growth was assessed. The research work focus on to evaluate the potential of Chlorella vulgaris on reduction of physicochemical properties and azo compounds in textile wastewater. Treatment of textile wastewater with $C$. vulgaris is carried out for 28 days. The microalga is inoculated on four dilutions $(15 \%, 30 \%, 45 \% \& 60 \%)$ of textile wastewater. Cell count of Chlorella vulgaris and physicochemical parameters of the treated and untreated wastewater is enumerated once in seven days interval for 28 days. Degradation of azo compounds on treated and untreated wastewater by Chlorella vulgaris was confirmed by GCMS and FTIR analysis. The results confirm that Chlorella vulgaris DPSF01 has improved the quality of textile wastewater to meet its permissible limits for discharge into the environment.
\end{abstract}

Keywords: Azo compounds, Chlorella vulgaris, FTIR, GCMS, Physicochemical properties, Textile wastewater,

\section{INTRODUCTION}

Textile industries are one of the rapid growing sectors in India. There are 21,076 textile units in India of which 5,285 units in Tamilnadu'. Textile processing includes sizing, de-sizing, scouring, bleaching, dyeing, rinsing and finishing. Thus, the textile effluent consists of different pollutants (dyes, surfactants, acid, bases, salts, heavy metals and addictives like anti-foaming and whitening agent, etc. $)^{2}$. One kilogram of cloth production requires 45 to $60 \mathrm{~L}$ of water hence textile industry is one of the high consumer of water in all over the world ${ }^{3}$.
In the treatment of textile effluent, bio-technological methods reveal the best comparing to the physical and chemical methods. Due to the long growth and less decolourization factor, fungal system becomes unfit for the bioremediation of textile effluent ${ }^{4}$. In case of bacteria, decolourization of textile dye is 60 to $80 \%$ on cultivation of 44 hours $^{5}$. Microalgae are the best in the remediation of textile effluent by removal of nitrogen, phosphorus and carbon from wastewater, thereby reducing eutrophication ${ }^{6}$. Micro-algae are capable of sequestering carbon dioxide in seawater, industrial wastewater, salt 
marshes, sewage wastewater and diverse wastewater by which reduces greenhouse effect ${ }^{7}$.

The use of micro-algae or macro-algae for the removal of pollutants from wastewater is known as phycoremediation. Number of micro-algae like Chlorella marina, Isochrysis galbana, Tetraselmis sp, Nanochloropsis sp and Dunaliella salina are concluded as the best tool in the removal of textile dye from the effluent ${ }^{8}$. The objective of the current research is to investigate the reduction of physicochemical parameters $\mathrm{pH}$, EC, Biochemical Oxygen Demand (BOD), Chemical Oxygen Demand (COD), Total Solids (TS), Total Dissolved Solids (TDS), Total Hardness (TH), Chloride, Bicarbonate, Magnesium, Ammoniacal nitrogen and Phosphate), heavy metals (Copper, Zinc Chromium, Iron and Nickel), and functional groups from the textile wastewater.

\section{Methodology}

Stock culture of micro-algae

Chlorella vulgaris DPSF01 was obtained from the Department of Marine Science, Bharathidasan University, Tiruchirappalli, Tamilnadu, India. The culture was grown on Bold's Basal Medium (BBM) at optimum condition of $20 \pm 23^{\circ} \mathrm{C}$ with $12 \mathrm{~h}$. light and $12 \mathrm{~h}$. dark ${ }^{9}$. All the chemicals were purchased from Merck, Mumbai, India.

\section{Collection and source of textile wastewater}

The wastewater was collected from a textile garment located at Tiruppur, Tamilnadu. Tiruppur is the fourth largest city in Tamilnadu with latitude $11.1085^{\circ} \mathrm{N}$ and longitude $77.3411^{\circ} \mathrm{E}$. The garment undergoes physical, chemical and biological methods to treat the textile wastewater before final discharge. The wastewater was collected in a sterile cane and was stored at $4^{\circ} \mathrm{C}$ for further deactivation. The physical ( $\mathrm{pH}$ and $\mathrm{EC}$ ) and chemical parameters (BOD, COD, TS, TDS, TH, chloride, magnesium, phosphate, ammoniacal nitrogen and bicarbonate) of the wastewater were analysed according to the APHA methods (1989).

\section{Experimental procedure of phycoremediation}

Four dilutions of textile wastewater were done which are $15 \%$ of textile wastewater was diluted with tap water $\left(D_{1}\right), 30 \%$ of textile wastewater was diluted with tap water $\left(D_{2}\right), 45 \%$ of textile wastewater was diluted with tap water $\left(D_{3}\right), 60 \%$ of textile wastewater was diluted with tap water $\left(D_{4}\right), 75 \%$ of textile wastewater was diluted with tap water $\left(D_{5}\right)$ and $100 \%$ raw textile wastewater $\left(D_{6}\right)^{11} .75 \%$ and $100 \%$ were not used in the experiment because of micro-alga growth was not observed.

\section{Analysis of algal cell count}

The cell count was determined using haemocytometer and microscope. The procedure for the cell count was followed by Lackey Drop Micro Transect method ${ }^{12}$. Algal count was enumerated at the interval of seven days $\left(7^{\text {th }}, 14^{\text {th }}, 21^{\text {st }}\right.$ and $28^{\text {th }}$ day).

\section{Chlorophyll estimation}

A $20 \mathrm{ml}$ of culture was centrifuged at 10,000 rpm for 10 minutes. The pellet was mixed with DMSO and again the mixture was centrifuged at $5000 \mathrm{rpm}$ for $10 \mathrm{~min}$. for re-extraction. After centrifugation, the supernatant was measured at $645 \mathrm{~nm}$ and $663 \mathrm{~nm}$ absorbance in spectrophotometer according to Arnon (1949).

\section{Analysis of physicochemical parameters}

The collected wastewater was subjected to physical and chemical tests such as $\mathrm{pH}, \mathrm{EC}$, BOD, COD, TS, TDS, TH, chloride, magnesium, phosphate, ammoniacal nitrogen and bicarbonate. The physicochemical parameters were estimated by APHA (1989) at the interval of seven days $\left(7^{\text {th }}, 14^{\text {th }}\right.$, $21^{\text {st }}$ and $28^{\text {th }}$ day). $\mathrm{pH}$ and electrical conductivity of the treated and untreated wastewater was assessed using ELICO model - 107 and ELICO model - 180 respectively. To analyse $\mathrm{BOD}$, the sample and blank (dilution water) was incubated at $20^{\circ} \mathrm{C}$ for five days. Initial DO was measured for both blank and sample before five days and final DO was measured after five days. BOD is the difference between initial DO and final DO. The COD was quantified by stirring the sample with ferroin indicator and titrating against ferrous ammonium sulphate solution. The variation in the volume of blank and sample on titration is the measure of COD. Total hardness of the treated and untreated wastewater was estimated using EDTAtrimetric method. The amount of $\mathrm{CaCO}_{3}$ in the water represents the total hardness of the water. Protocol of Nesslerisation method was followed to determine the ammoniacal nitrogen of treated and untreated wastewater. Chloride ion is the major inorganic anion in wastewater and was measured by titrating 
the sample against silver nitrate solution. Estimation of phosphate in treated and untreated wastewater was done using membrane filtration technique. Total solids and total dissolved solids were analysed before and after treatment using the Whatmann filter paper. Heavy metals were analysed using Atomic Adsorption Spectrophotometer (1983-400 HGA 900/ AS 800 Perkin Elmer) and Multi-Element Standard (Merck-112837) during the time interval of 7 days (14).

\section{Statistical analysis}

Experiments were carried out with three replications. Results were presented with the means \pm standard errors for all the three replicates.

\section{FTIR and GCMS analysis}

Fourier transformed infrared spectral analysis was used to determine the functional groups on the cell surface of micro-algae before and after treatment. The spectra were recorded on the wavelength between $4000-400 \mathrm{~cm}^{-1}$ using FTIR spectroscopy of model Perkin-Elmer 1725x. Raw and treated wastewater were mixed with the mixture of methanol and water (9:1) and incubated in shaker for overnight at room temperature. The sample was filtered using Whatmann filter paper and dried in hot air oven. After drying, the pellet was collected ${ }^{15}$. Degradation of azo compounds was determined by GC-MS Thermo MS DSQ II, gas carrier helium $\left(1.0 \mathrm{ml} / \mathrm{min}\right.$.), capillary column ${ }^{16}$.

\section{RESULTS AND DISCUSSION}

\section{Analysis of algal growth}

Algal cell count was found to be $785 \times 103$ cells $\mathrm{mL}^{-1}$ in $\mathrm{D} 1$ on the 28th day whereas in $\mathrm{D}_{3}$ and $\mathrm{D}_{4}$ limited growth was observed. High growth of algae in textile wastewater was observed due to the presence of carbon, nitrogen, phosphorus, salt and toxicants like benzidine and naphthalene limited the growth of algae ${ }^{17,18}$. The lowest algal cells $(442 \times 103$ cells $\mathrm{mL}^{-1}$ ) were found in $\mathrm{D}_{4}$ dilution (Figure 1).

\section{Chlorophyll count on textile wastewater}

Chlorophyll count was found to be high in $D_{1}$ and $D_{2}$, due to higher dilution (Fig. 2). Maximum count of chlorophyll a was $0.73 \mu \mathrm{g} / \mathrm{ml}$ and chlorophyll b was $0.26 \mu \mathrm{g} / \mathrm{ml}$ in $D_{1}$ dilution on the $28^{\text {th }}$ day of the treatment. The colour change of textile wastewater from dark green to algal green was due to the high count of chlorophyll a and $b^{19}$.

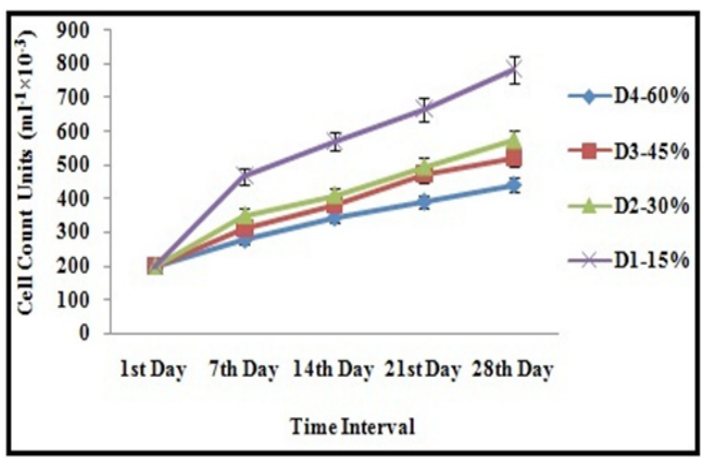

Fig. 1. Cell count of $C$. vulgaris on different concentration of textile wastewater

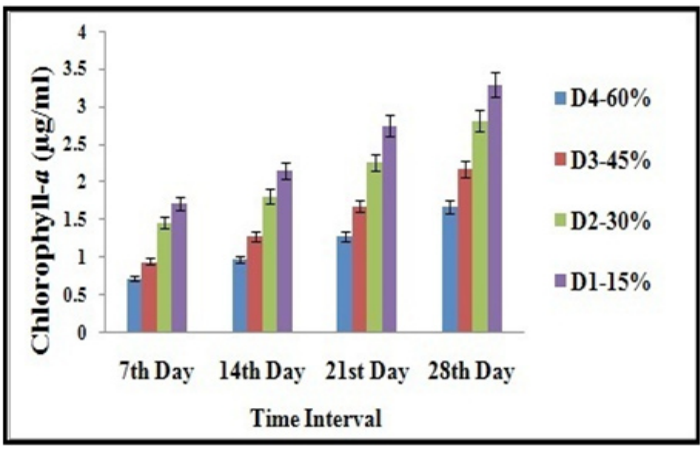

(a)

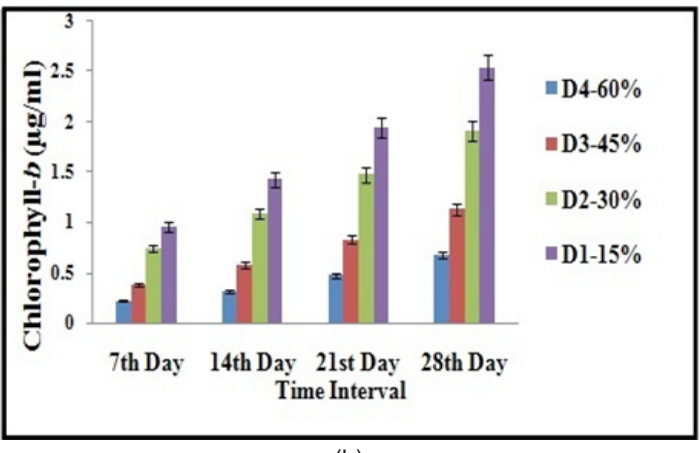

(b)

Fig. 2. Estimation of chlorophyll-a and $b$ on different concentration of textile wastewater

\section{Physicochemical parameters of raw and treated textile wastewater}

Physicochemical parameters of treated and untreated wastewater were shown in the Table $1 \& 2$. The change in $\mathrm{pH}$ from neutral (6.25) to basic (8.63) was due to the photosynthesis of microalga which reduces the concentration of dissolved $\mathrm{CO}_{2}{ }^{20}$. The electrical conductivity of textile wastewater was reduced from $11.08 \mathrm{dsm}^{-1}$ to $1.84 \mathrm{dsm}^{-1}$ after the 
treatment with $C$. vulgaris. High value of BOD made the water unable to receive the dissolved oxygen leading to anaerobiosis which killed the aquatic organisms ${ }^{21}$. In the present study, C. vulgaris was able to reduce BOD from $782 \mathrm{mg} \mathrm{L}^{-1}$ to $121 \mathrm{mg} \mathrm{L}^{-1}$ after the treatment thereby, reducing the toxicity level. The bioconversion of carbon in organic pollutants to $\mathrm{CO}_{2}$ by $C$. vulgaris was reduced COD from $1700 \mathrm{mg}$ $\mathrm{L}^{-1}$ to $243 \mathrm{mg} \mathrm{L}^{-122}$. Removal of TDS from $4923 \mathrm{mg}$ $\mathrm{L}^{-1}$ to $753 \mathrm{mg} \mathrm{L}^{-1}$ was due to the unique mechanism of biosorption by $C$. vulgaris ${ }^{23}$. The reduction of total hardness from $1054 \mathrm{mg} \mathrm{L}^{-1}$ to $368 \mathrm{mg} \mathrm{L}^{-1}$ was due to the precipitation of $\mathrm{CaCO}_{3}$ by micro-algae for their growth ${ }^{24}$. The uptake of ammoniacal nitrogen from textile wastewater (10 $\mathrm{mg} \mathrm{L}^{-1}$ to $5.86 \mathrm{mg} \mathrm{L}^{-1}$ ) was achieved by the process of denitrification by C. vulgaris ${ }^{25}$. The uptake of phosphate from wastewater was mainly for the usage of phosphorus for ATP and nucleic acid production ${ }^{26}$. After the treatment of textile wastewater with $C$. vulgaris the magnesium was reduced from $87 \mathrm{mg} \mathrm{L}^{-1}$ to $30 \mathrm{mg}$ $\mathrm{L}^{-1}$. As the heavy metals were below the permissible limits of BIS-1994 ${ }^{27}$ in raw textile wastewater and the further analysis of heavy metals was not done.

\section{FT-IR analysis of treated and untreated textile wastewater}

Figure 3 shows the functional group analysis of treated and untreated wastewater. A broad peak at $3437 \mathrm{~cm}^{-1}$ represents $\mathrm{NH}_{2}$ group of aromatic amines. The wave number of $2269 \mathrm{~cm}^{-1}$ exhibits the stretching of $\mathrm{N} \equiv \mathrm{N}$ in diazonium salts. The region between $1539 \mathrm{~cm}^{-1}-1580 \mathrm{~cm}^{-1}$ indicates the presence of azo group. The wave number $1346 \mathrm{~cm}^{-1}$ confirms the presence of $\mathrm{SO}_{2}$ in sulfonamides. The $\mathrm{C}-\mathrm{OH}$ group of alcohol in raw textile wastewater is denoted by the peak value of $1058 \mathrm{~cm}^{-1}$.

The $\mathrm{O}-\mathrm{H}$ and $\mathrm{N}-\mathrm{H}$ functional groups appear between the regions of $3200 \mathrm{~cm}^{-1}$ to 3600 $\mathrm{cm}^{-1}$. The spectral value of $2925 \mathrm{~cm}^{-1}$ indicates $\mathrm{CH}_{2}$ group in lipid of $C$. vulgaris ${ }^{28}$. The wave number $2410 \mathrm{~cm}^{-1}$ represents the $\mathrm{pH}$ group of phosphines. The involvement of $\mathrm{C}-\mathrm{O}-\mathrm{C}$ group of polysaccharide is seen in the region of $1144 \mathrm{~cm}^{-129}$. The polysaccharides present in the cell wall binds metal ions by electrostatic forces which enhances the process of biosorption ${ }^{30}$. The peak of $1653 \mathrm{~cm}^{-1}$ indicates the functional group $\mathrm{C}=\mathrm{O}$ in ketone esters proving the degradation of azo compounds by C. vulgaris.

Table 1: Physicochemical properties of textile wastewater before and after treatment

\begin{tabular}{|c|c|c|c|}
\hline S.NO & Parameters & Raw Effluent & Treated Effluent \\
\hline 1 & $\mathrm{pH}$ & $6.25 \pm 0.16$ & $8.63 \pm 0.20$ \\
\hline 2 & $\mathrm{EC}\left(\mathrm{dsm}^{-1}\right)$ & $11.08 \pm 0.05$ & $1.84 \pm 0.17$ \\
\hline 3 & Biochemical Oxygen Demand (mg L-1) & $782 \pm 8.02$ & $121 \pm 8.50$ \\
\hline 4 & Chemical Oxygen Demand (mg L-1) & $1700 \pm 11.53$ & $243 \pm 4.35$ \\
\hline 5 & Total Solids $\left(\mathrm{mg} \mathrm{L}^{-1}\right)$ & $5483 \pm 12.58$ & $1209 \pm 6.65$ \\
\hline 6 & Total Dissolved Solids $\left(\mathrm{mg} \mathrm{L}^{-1}\right)$ & $4923 \pm 8.96$ & $753 \pm 6.42$ \\
\hline 7 & Chloride $\left(\mathrm{mg} \mathrm{L}^{-1}\right)$ & $286 \pm 7$ & $106 \pm 7.37$ \\
\hline 8 & Total hardness $\left(\mathrm{mg} \mathrm{L}^{-1}\right)$ & $1054 \pm 6.42$ & $368 \pm 7.93$ \\
\hline 9 & Bicarbonate $\left(\mathrm{mg} \mathrm{L}^{-1}\right)$ & $541 \pm 5.50$ & $268 \pm 9.64$ \\
\hline 10 & Magnesium (mg L-1) & $87 \pm 4.93$ & $30 \pm 2.88$ \\
\hline 11 & Ammoniacal Nitrogen $\left(\mathrm{mg} \mathrm{L}^{-1}\right)$ & $10 \pm 4.35$ & $5.86 \pm 0.14$ \\
\hline 12 & Phosphate $\left(\mathrm{mg} \mathrm{L}^{-1}\right)$ & $12 \pm 4.61$ & $6.87 \pm 0.21$ \\
\hline \multicolumn{4}{|c|}{ Heavy Metals (ppb) } \\
\hline 1 & Copper & $4.23 \pm 0.08$ & - \\
\hline 2 & Zinc & $3.32 \pm 0.04$ & - \\
\hline 3 & Chromium & $3.56 \pm 0.05$ & - \\
\hline 4 & Iron & $17.77 \pm 0.20$ & - \\
\hline 5 & Nickel & $0.29 \pm 0.03$ & - \\
\hline
\end{tabular}


Table 2: Evaluation of physicochemical parameters during phycoremediation of textile wastewater

\begin{tabular}{|c|c|c|c|c|c|}
\hline \multicolumn{6}{|c|}{$\begin{array}{c}\text { Physical Parameters } \\
\text { pH Variations }\end{array}$} \\
\hline Treatments & $1^{\text {st }}$ day & $7^{\text {th }}$ day & $14^{\text {th }}$ day & $21^{\text {st }}$ day & $28^{\text {th }}$ day \\
\hline Control & $6.25 \pm 0.16$ & $6.25 \pm 0.10$ & $6.25 \pm 0.06$ & $6.25 \pm 0.08$ & $6.25 \pm 0.09$ \\
\hline $\mathrm{T}_{3}(60 \%)$ & $6.88 \pm 0.20$ & $6.90 \pm 0.13$ & $6.95 \pm 0.05$ & $7.22 \pm 0.10$ & $7.52 \pm 0.13$ \\
\hline $\mathrm{T}_{4}(45 \%)$ & $7.02 \pm 0.15$ & $7.21 \pm 0.16$ & $7.46 \pm 0.17$ & $7.64 \pm 0.06$ & $7.83 \pm 0.18$ \\
\hline $\mathrm{T}_{5}(30 \%)$ & $7.55 \pm 0.12$ & $7.92 \pm 0.22$ & $8.12 \pm 0.14$ & $8.28 \pm 0.09$ & $8.38 \pm 0.22$ \\
\hline $\mathrm{T}_{6}(15 \%)$ & $8 \pm 0.09$ & $8.21 \pm 0.15$ & $8.33 \pm 0.11$ & $8.46 \pm 0.10$ & $8.63 \pm 0.20$ \\
\hline \multicolumn{6}{|c|}{ Electrical Conductivity $\left(\mathrm{dSm}^{-1}\right)$} \\
\hline Control & $11.08 \pm 0.05$ & $11.08 \pm 0.03$ & $11.08 \pm 0.09$ & $11.08 \pm 0.10$ & $11.08 \pm 0.06$ \\
\hline $\mathrm{T}_{3}(60 \%)$ & $9.22 \pm 0.08$ & $9.12 \pm 0.09$ & $9.05 \pm 0.10$ & $9.00 \pm 0.07$ & $8.96 \pm 0.12$ \\
\hline $\mathrm{T}_{4}(45 \%)$ & $7.38 \pm 0.10$ & $7.22 \pm 0.16$ & $7.08 \pm 0.11$ & $6.93 \pm 0.10$ & $6.74 \pm 0.10$ \\
\hline $\mathrm{T}_{5}(30 \%)$ & $5.55 \pm 0.13$ & $5.26 \pm 0.14$ & $4.94 \pm 0.15$ & $4.69 \pm 0.13$ & $4.37 \pm 0.16$ \\
\hline$T_{6}(15 \%)$ & $3.42 \pm 0.12$ & $3.03 \pm 0.13$ & $2.68 \pm 0.19$ & $2.28 \pm 0.16$ & $1.84 \pm 0.17$ \\
\hline \multicolumn{6}{|c|}{ Chemical Parameters } \\
\hline Treatments & $1^{\text {st }}$ day & $7^{\text {th }}$ day & $14^{\text {th }}$ day & $21^{\text {st }}$ day & $28^{\text {th }}$ day \\
\hline Control & $782 \pm 8.02$ & $782 \pm 9.26$ & $782 \pm 8.08$ & $782 \pm 11.06$ & $782 \pm 12.74$ \\
\hline $\mathrm{T}_{3}(60 \%)$ & $760 \pm 13.86$ & $711 \pm 11.93$ & $666 \pm 10.65$ & $615 \pm 15.94$ & $566 \pm 13.65$ \\
\hline $\mathrm{T}_{4}(45 \%)$ & $744 \pm 8.76$ & $663 \pm 9.90$ & $577 \pm 13.89$ & $494 \pm 11.40$ & $419 \pm 15.02$ \\
\hline $\mathrm{T}_{5}(30 \%)$ & $737 \pm 12.49$ & $620 \pm 8.14$ & $501 \pm 8.38$ & $386 \pm 11.62$ & $268 \pm 10.69$ \\
\hline $\mathrm{T}_{6}(15 \%)$ & $725 \pm 9.26$ & $574 \pm 10.10$ & $426 \pm 12.42$ & $271 \pm 10.52$ & $121 \pm 8.50$ \\
\hline \multicolumn{6}{|c|}{ Chemical Oxygen Demand (mg L-1) } \\
\hline Control & $1700 \pm 11.53$ & $1700 \pm 15.27$ & $1700 \pm 15.13$ & $1700 \pm 10.58$ & $1700 \pm 10.58$ \\
\hline T3 $(60 \%)$ & $1669 \pm 7.57$ & $1582 \pm 10.81$ & $1491 \pm 6.35$ & $1393 \pm 9.29$ & $1297 \pm 5.85$ \\
\hline T4 (45\%) & $1648 \pm 8.32$ & $1480 \pm 6.42$ & $1315 \pm 7.21$ & $1147 \pm 7.93$ & $976 \pm 6.80$ \\
\hline T5 (30\%) & $1629 \pm 11.59$ & $1379 \pm 5.50$ & $1137 \pm 6.08$ & $882 \pm 6.42$ & $624 \pm 8.71$ \\
\hline T6 (15\%) & $1609 \pm 8.50$ & $1268 \pm 7$ & $923 \pm 5.50$ & $583 \pm 9.53$ & $243 \pm 4.35$ \\
\hline \multicolumn{6}{|c|}{ Total Solids $\left(\mathrm{mg} \mathrm{L}^{-1}\right)$} \\
\hline Control & $5483 \pm 12.58$ & $5483 \pm 13.07$ & $5483 \pm 8.08$ & $5483 \pm 9.84$ & $5483 \pm 12.34$ \\
\hline $\mathrm{T}_{3}(60 \%)$ & $5297 \pm 6.35$ & $5170 \pm 7$ & $5038 \pm 7.81$ & $4907 \pm 10.21$ & $4776 \pm 7.37$ \\
\hline $\mathrm{T}_{4}(45 \%)$ & $5270 \pm 9.29$ & $4857 \pm 10.40$ & $4449 \pm 9.16$ & $4039 \pm 8.71$ & $3620 \pm 10.96$ \\
\hline $\mathrm{T}_{5}(30 \%)$ & $5129 \pm 10.96$ & $4466 \pm 10.01$ & $3796 \pm 8.38$ & $3123 \pm 7.93$ & $2431 \pm 8.50$ \\
\hline $\mathrm{T}_{6}(15 \%)$ & $5003 \pm 6.08$ & $4055 \pm 10.58$ & $3114 \pm 10.81$ & $2163 \pm 6.80$ & $1209 \pm 6.65$ \\
\hline \multicolumn{6}{|c|}{ Total Dissolved Solids (mg L-1) } \\
\hline Control & $4923 \pm 8.96$ & $4923 \pm 9.29$ & $4923 \pm 7.81$ & $4923 \pm 8.18$ & $4923 \pm 7.26$ \\
\hline $\mathrm{T}_{3}(60 \%)$ & $4688 \pm 6.24$ & $4584 \pm 6.65$ & $4484 \pm 6.55$ & $4375 \pm 5.19$ & $4273 \pm 5.29$ \\
\hline $\mathrm{T}_{4}(45 \%)$ & $4620 \pm 7.23$ & $4309 \pm 7.57$ & $4003 \pm 7.21$ & $3692 \pm 5.77$ & $3377 \pm 8.14$ \\
\hline $\mathrm{T}_{5}(30 \%)$ & $4545 \pm 6.80$ & $3694 \pm 5.68$ & $3389 \pm 6.42$ & $2809 \pm 7$ & $2222 \pm 7.09$ \\
\hline $\mathrm{T}_{6}(15 \%)$ & $4453 \pm 5.68$ & $3528 \pm 5.50$ & $2600 \pm 7.51$ & $1670 \pm 6.08$ & $753 \pm 6.42$ \\
\hline \multicolumn{6}{|c|}{ Total Hardness $\left(\mathrm{mg} \mathrm{L}^{-1}\right)$} \\
\hline Control & $1054 \pm 6.42$ & $1054 \pm 6.65$ & $1054 \pm 6.08$ & $1054 \pm 7.93$ & $1054 \pm 7.81$ \\
\hline $\mathrm{T}_{3}(60 \%)$ & $1049 \pm 9.86$ & $1028 \pm 8.41$ & $1010 \pm 7.23$ & $990 \pm 7.37$ & $967 \pm 9.64$ \\
\hline $\mathrm{T}_{4}(45 \%)$ & $1044 \pm 7$ & $990 \pm 7.81$ & $931 \pm 6.80$ & $873 \pm 5.85$ & $831 \pm 6.92$ \\
\hline $\mathrm{T}_{5}(30 \%)$ & $1036 \pm 5.85$ & $929 \pm 7.57$ & $828 \pm 6.42$ & $720 \pm 6.92$ & $611 \pm 8.71$ \\
\hline $\mathrm{T}_{6}(15 \%)$ & $1028 \pm 8.32$ & $863 \pm 6.11$ & $695 \pm 6.65$ & $535 \pm 6.80$ & $368 \pm 7.93$ \\
\hline \multicolumn{6}{|c|}{ Chloride $\left(\mathrm{mg} \mathrm{L}^{-1}\right)$} \\
\hline Control & $286 \pm 7$ & $286 \pm 6.65$ & $286 \pm 8.50$ & $286 \pm 6.42$ & $286 \pm 8.38$ \\
\hline $\mathrm{T}_{3}(60 \%)$ & $278 \pm 6.24$ & $274 \pm 5.85$ & $271 \pm 4.93$ & $268 \pm 6.08$ & $264 \pm 6.11$ \\
\hline $\mathrm{T}_{4}(45 \%)$ & $274 \pm 7.23$ & $261 \pm 8.32$ & $250 \pm 8.96$ & $238 \pm 7.63$ & $225 \pm 5.29$ \\
\hline
\end{tabular}




\begin{tabular}{|c|c|c|c|c|c|}
\hline $\mathrm{T}_{5}(30 \%)$ & $269 \pm 7.21$ & $244 \pm 8.38$ & $222 \pm 7$ & $198 \pm 7.57$ & $171 \pm 6.35$ \\
\hline $\mathrm{T}_{6}(15 \%)$ & $265 \pm 5.68$ & $225 \pm 7.81$ & $180 \pm 5.50$ & $137 \pm 5.29$ & $106 \pm 7.37$ \\
\hline \multicolumn{6}{|c|}{ Bicarbonate $\left(\mathrm{mg} \mathrm{L}^{-1}\right)$} \\
\hline Control & $541 \pm 5.50$ & $541 \pm 5.85$ & $541 \pm 6.65$ & $541 \pm 5.68$ & $541 \pm 7.93$ \\
\hline $\mathrm{T}_{3}(60 \%)$ & $531 \pm 6.24$ & $524 \pm 8.50$ & $519 \pm 8.38$ & $513 \pm 6.92$ & $503 \pm 9.64$ \\
\hline $\mathrm{T}_{4}(45 \%)$ & $526 \pm 5.77$ & $506 \pm 6.80$ & $484 \pm 5.56$ & $463 \pm 6.08$ & $447 \pm 7.63$ \\
\hline $\mathrm{T}_{5}(30 \%)$ & $520 \pm 6.08$ & $480 \pm 5.29$ & $438 \pm 7.93$ & $398 \pm 6.24$ & $362 \pm 7.37$ \\
\hline $\mathrm{T}_{6}(15 \%)$ & $513 \pm 5.85$ & $451 \pm 11.14$ & $388 \pm 7$ & $328 \pm 7.81$ & $268 \pm 9.64$ \\
\hline \multicolumn{6}{|c|}{ Magnesium $\left(\mathrm{mg} \mathrm{L}^{-1}\right)$} \\
\hline Control & $87 \pm 4.93$ & $87 \pm 8.66$ & $87 \pm 5.29$ & $87 \pm 7.37$ & $87 \pm 4.04$ \\
\hline $\mathrm{T}_{3}(60 \%)$ & $84 \pm 6.42$ & $83 \pm 7.23$ & $81 \pm 5.13$ & $80 \pm 4.93$ & $79 \pm 4.61$ \\
\hline $\mathrm{T}_{4}^{0}(45 \%)$ & $81 \pm 5.19$ & $77 \pm 4.72$ & $74 \pm 6.08$ & $71 \pm 7.51$ & $67 \pm 5.68$ \\
\hline $\mathrm{T}_{5}(30 \%)$ & $79 \pm 5.50$ & $72 \pm 5.29$ & $66 \pm 5.85$ & $59 \pm 8.50$ & $52 \pm 4.35$ \\
\hline $\mathrm{T}_{6}(15 \%)$ & $77 \pm 7.57$ & $65 \pm 6.24$ & $55 \pm 7.93$ & $44 \pm 5.03$ & $30 \pm 2.88$ \\
\hline \multicolumn{6}{|c|}{ Ammoniacal Nitrogen $\left(\mathrm{mg} \mathrm{L}^{-1}\right)$} \\
\hline Control & $10 \pm 1.85$ & $10 \pm 1.45$ & $10 \pm 1.20$ & $10 \pm 0.66$ & $10 \pm 0.57$ \\
\hline $\mathrm{T}_{3}(60 \%)$ & $9.97 \pm 0.20$ & $9.81 \pm 0.11$ & $9.69 \pm 0.12$ & $9.51 \pm 0.19$ & $9.32 \pm 0.13$ \\
\hline $\mathrm{T}_{4}(45 \%)$ & $9.92 \pm 0.14$ & $9.55 \pm 0.16$ & $9.17 \pm 0.18$ & $8.78 \pm 0.13$ & $8.44 \pm 0.21$ \\
\hline $\mathrm{T}_{5}^{4}(30 \%)$ & $9.86 \pm 0.21$ & $9.21 \pm 0.15$ & $8.61 \pm 0.24$ & $7.92 \pm 0.08$ & $7.24 \pm 0.09$ \\
\hline $\mathrm{T}_{6}(15 \%)$ & $9.80 \pm 0.09$ & $8.82 \pm 0.10$ & $7.81 \pm 0.16$ & $6.81 \pm 0.11$ & $5.86 \pm 0.14$ \\
\hline \multicolumn{6}{|c|}{ Phosphate $\left(\mathrm{mg} \mathrm{L}^{-1}\right)$} \\
\hline Control & $12 \pm 1.73$ & $12 \pm 2.08$ & $12 \pm 2.30$ & $12 \pm 1.52$ & $12 \pm 2$ \\
\hline $\mathrm{T}_{3}(60 \%)$ & $11.80 \pm 0.17$ & $11.67 \pm 0.16$ & $11.57 \pm 0.14$ & $11.42 \pm 0.12$ & $11.27 \pm 0.09$ \\
\hline $\mathrm{T}_{4}(45 \%)$ & $11.64 \pm 0.08$ & $11.32 \pm 0.09$ & $10.96 \pm 0.11$ & $10.56 \pm 0.16$ & $10.07 \pm 0.20$ \\
\hline $\mathrm{T}_{5}(30 \%)$ & $11.42 \pm 0.19$ & $10.73 \pm 0.20$ & $10.08 \pm 0.10$ & $9.38 \pm 0.13$ & $8.65 \pm 0.26$ \\
\hline $\mathrm{T}_{6}(15 \%)$ & $11.29 \pm 0.18$ & $10.18 \pm 0.08$ & $9.08 \pm 0.13$ & $7.96 \pm 0.09$ & $6.87 \pm 0.21$ \\
\hline
\end{tabular}
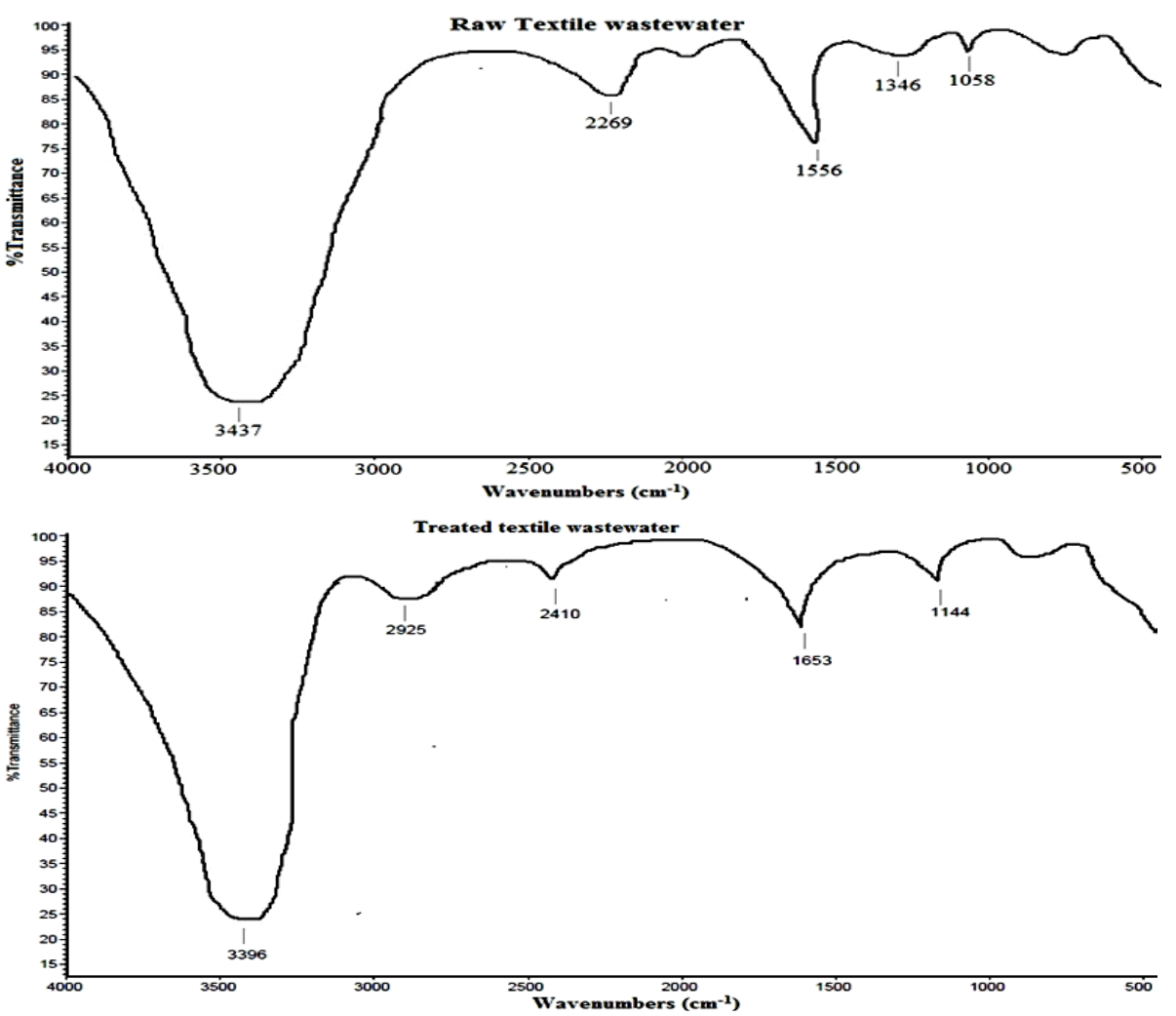

Fig. 3. Spectral analysis of raw and algal treated textile wastewater 


\section{GC-MS analysis of treated and untreated textile wastewater}

Figure $4 \mathrm{a}$ and $\mathrm{b}$ shows the degradation of azo compounds by $C$. vulgaris. Azo compounds present in raw textile wastewater are 4-Imidazolacetic acid butyl ester (Mol wt: 182; RT: 11.49), N-[2(3-methylphenoxy)ethyl]-1 $\mathrm{H}^{-1}, 2,4$-triazole5-carboxamide (Mol wt:246; RT: 30.99) and 5-(3,4-Bis[(trimethylsilyl)oxy]-1,5-cyclohexadien1-yl)-3-methyl-5-phenyl-1-(trimethylsilyl)-2,4imidazolidinedione (Mol wt: 516; RT: 34.29). After the treatment with $C$. vulgaris the textile wastewater is lack of these azo compounds completely. The azo reductase of $\mathrm{C}$. vulgaris is responsible for the breakdown of $\mathrm{N}=\mathrm{N}$ in azo compound ${ }^{31}$.
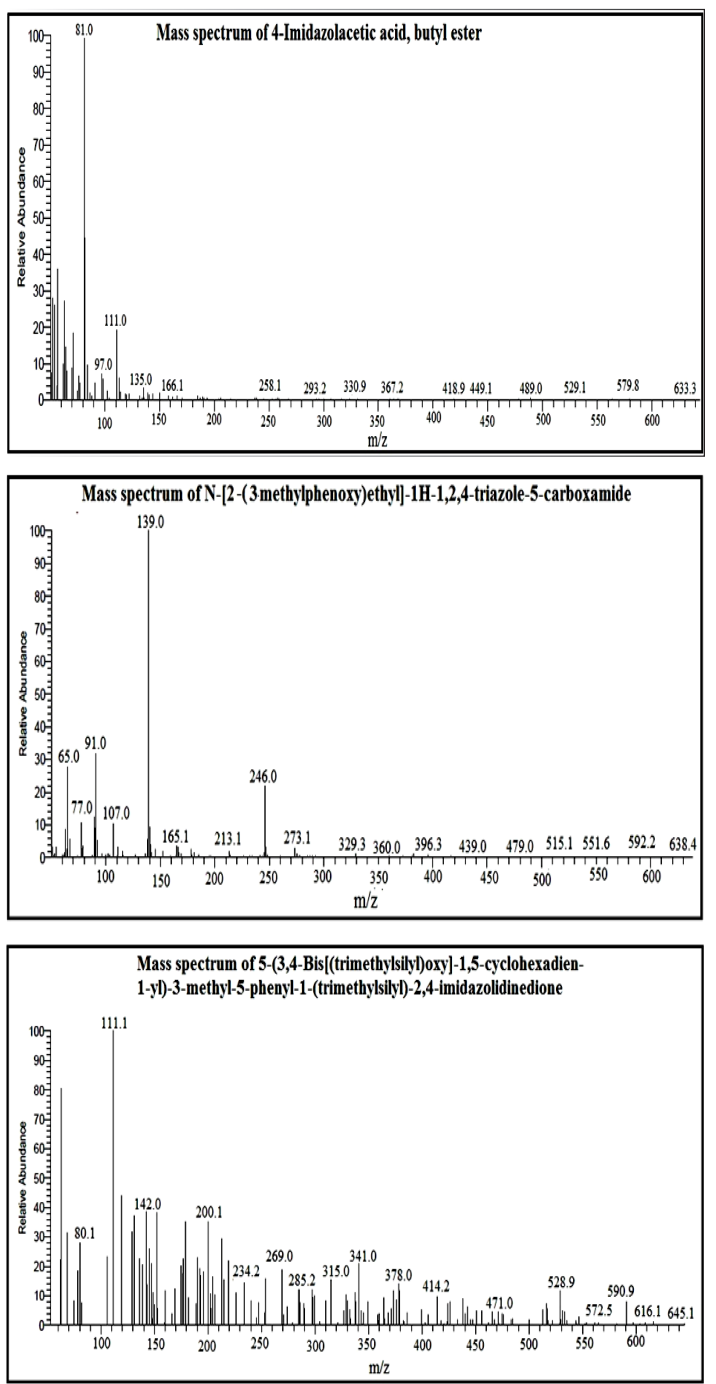

Fig. 4a. GC-MS chromatogram of raw textile wastewater
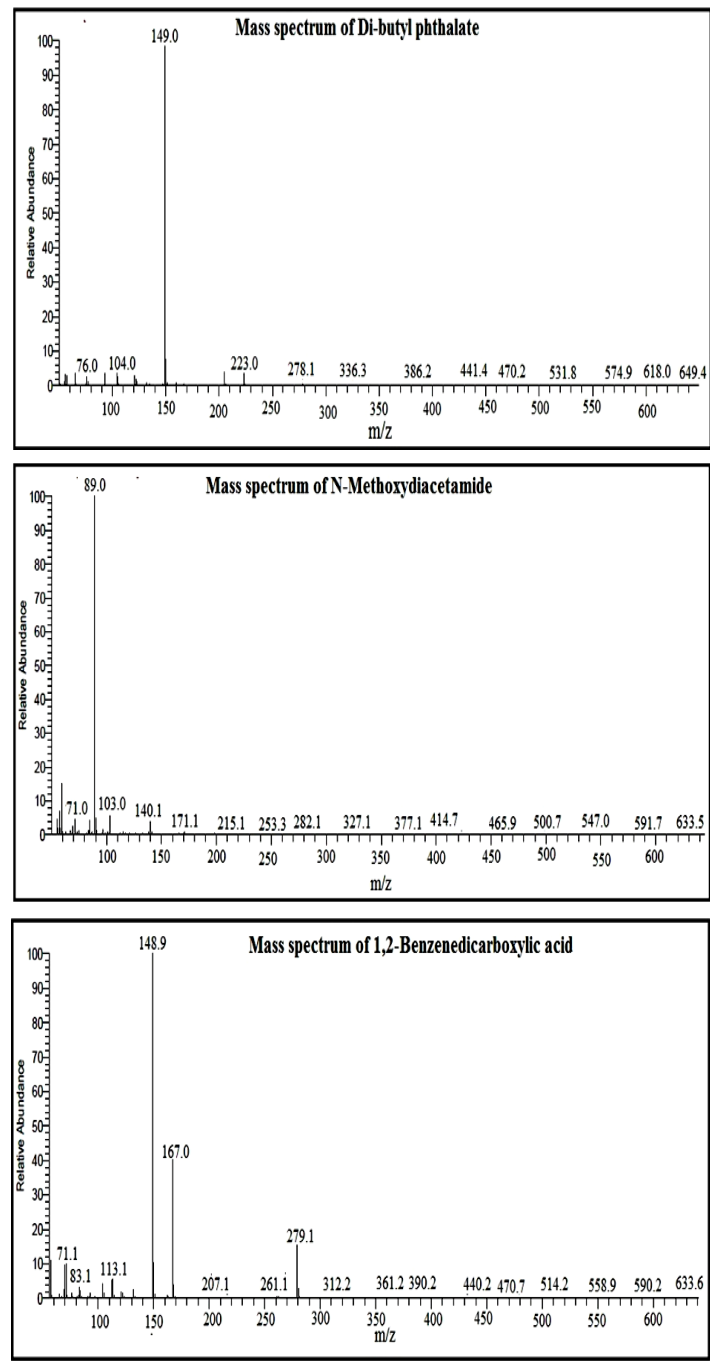

Fig. 4b. GC-MS chromatogram of algal treated textile wastewater

\section{CONCLUSION}

The present study suggests that $C$. vulgaris is a suitable tool for the bio-remediation of textile wastewater. Degradation of azo compounds by C. vulgaris reduces the toxicity of textile wastewater to a considerable level. Treatment of textile wastewater using $C$. vulgaris is cost-effective and the treated wastewater can also be analysed for plant growth. The usage of $C$. vulgaris treated textile wastewater for industrial purposes and the mechanism of heavy metal removal will be reviewed in future.

\section{ACKNOWLEDGMENT}

The research was supported by Bharathidasan University, Department of Environmental Science who provide us the $C$. vulgaris. 


\section{REFERENCES}

1. Bal, A.S. Indian. J. Environ. Health., 1999, 41, 264-290.

2. Zaharia, C.; Suteu, D. Textile organic dyes characteristics, polluting effects, and separation/elimination procedures from industrial effluents. A critical overview. In: Puzyn, T.; Mostrag- Szlichtyng, A. Organic pollutants-ten years after the Stockholm convention. Environmental and analytical update. (Intech Publisher Inc.) eds. Rijeka., 2012, 55-86.

3. Manu, B.; Chaudhari, S. Bioresour. Technol ., 2002, 82, 225-231.

4. Banat, I.M.; Nigam, P.; Singh, D.; Marchant, R. Bioresour. Technol., 1996, 58, 217-227.

5. Banat, I.M.; Nigam, G.; Mullam M.C.; Marchant, R. Environ. Int., 1997, 23, 547-551.

6. Olguin, E.J. Biotechnol. Adv., 2003, 22, 1-91.

7. Mata, T.M.; Martina, A.A.; Sikdar, S.; Costa, C.A.V. Clean. Technol. Environ. Policy., 2011, 13, 655-671.

8. Dinesh Kumar, P.; Santhanam, P.; Nandha kumar, R. Afr. J. Biotech., 2014, 22, 2288-2294.

9. Nichols, H.E. Growth media freshwater. Handbook of phycological methods: Culture methods and growth measurements. (Cambridge University press, Cambridge) ed. Stein, J., 1973, 7-24.

10. Clesceri, L.S.; Greenberg, A.E.; Trussel, R.R. Standard methods for the examination of water and wastewater. (17th edn, American Public Health Association, Washington, DC). 1989.

11. Cindrella, D.; Naseera, K.; Anirudh, R.; Ram Murti, M.; Nagappa, R. J. Appl. Phycol., 2016.

12. Lenore S Clesceri. Standard Methods for the Examination of Water and Wastewater;. 20th Edn, American Public Health Association, Washington, DC, USA. 1998.

13. Arnon, D.I. Plant physiology.,1949, 24, 1-15.

14. Fraile, A.; Penche, S.; González, F.; Blázquez, M.L.; Muñoz, J.A.; Ballester, A. Chemistry and Ecology., 2005, 21, 61-75.

15. Dilek Yalcin, D.; Abel, U.; Udoh, Tulay, O.; Aydin, A.; Ilkay Acikgoz, E;. Kazim, Y.; Deniz,
G. Afr. J. Biotech., 2012, 11, 3817-3824.

16. Sharma, S.; Shikha, R. Int. Res. J. Environ. Sci., 2015, 4, 44-53.

17. Elumalai, S.; Sarvanan, G.K.; Ramganesh, S.; Sakahivel R.; Prakasam, V. I. J. Sci. Inno. Dis., 2013, 3, 31-37.

18. Donmez, G.; Aksu, Z. Process. Biochem., 2002, 38, 751-762.

19. HanumanthaRao, P.;Ranjith Kumar, R.; Raghavan, B.G.; Subramanian, V.V.; Sivasubramanian, V. Water. SA., 2011, 37, 7-14.

20. S. Elumalai, G.K.; Saravanan, S.; Ramganesh, R.; Sakthivel, V.; Prakasam. I. J.S.I.D., 2013, 3, 31-37.

21. Choi, H-J.; Lee, S-M. Environ. Eng. Res., 2012, 17, 3-8.

22. Abdel-Raouf, N.; Al-Homaidan, A.A.; Ibraheem, I.B.M. Saudi. J. Biol. Sci., 2012, 19, 257-275.

23. Nanda, S.; Sarangi, P.K.; Abraham, J. N. Y. Sci J., 2010, 3, 37-41.

24. Sengar, R.M.S.; Singh, K.K.; Singh, S. Ind . J. Sci. Res., 2011, 2, 33-39.

25. Durai, G.; Rajasimman, M. J Env. Sci and Technol., 2011, 4, 1-17.

26. Becker, E.W. Microalgae-biotechnology and microbiology. Cambridge University Press, Cambridge. 1994.

27. Bureau of Indian Standards (BIS). Quality tolerance for water for Tanning industry. IS: 4221, New Delhi. 1994.

28. Benning, L.G.; Phoenix, V.R.; Yee, N.; Tobin, M.J. Geocimica et Cosmochimica Acta., 2004, 68, 729-741.

29. Brandenburg, K.; Seydel, U. Fourier transform infrared spectroscopy of cell surface polysaccharides. Infrared Spectroscopy of Biomolecules, (Wiley, Chichester) eds. Mantsch, H.H.; Chapman, D., 1996, 203-278.

30. Lau, P.S.; Lee, H.Y.; Tsang, C.C.K.; Tam, N.F.Y.; Wong, Y.S. Environ. Technol., 1999, 20, 953-961.

31. Lin, J.; Liu Houtian. Environ. Pollut., 1992, 75, 273-278. 